Utah State University

DigitalCommons@USU

The Bark Beetles, Fuels, and Fire Bibliography

Quinney Natural Resources Research Library,

S.J. and Jessie E.

1999

\title{
Effects of Thinning and Similar Stand Treatments on Fire Behavior in Western Forests
}

Russell T. Graham

Alan E. Harvey

Threasa B. Jain

Jonalea R. Tonn

Follow this and additional works at: https://digitalcommons.usu.edu/barkbeetles

Part of the Ecology and Evolutionary Biology Commons, Entomology Commons, Forest Biology

Commons, Forest Management Commons, and the Wood Science and Pulp, Paper Technology Commons

\section{Recommended Citation}

Graham, R., Harvey, A., Jain, T. and Tonn, J. (1999). Effects of thinning and similar stand treatments on fire behavior in western forests. USDA Forest Service, Pacific Northwest Research Station, General Technical Report PNW-GTR-463.

This Full Issue is brought to you for free and open access by the Quinney Natural Resources Research Library, S.J. and Jessie E. at DigitalCommons@USU. It has been accepted for inclusion in The Bark Beetles, Fuels, and Fire Bibliography by an authorized administrator of DigitalCommons@USU. For more information, please contact digitalcommons@usu.edu.

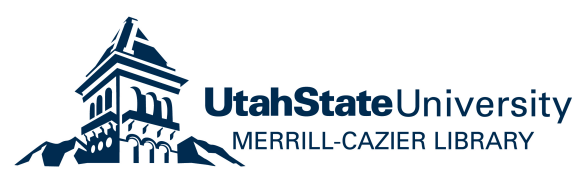


USDA

Department of

Agriculture

Forest Service

Pacific Northwest

Research Station

United States

Department of the

Interior

Bureau of Land

Management

General Technica

Report

PNW-GTR-463

September 1999

\section{ins}

\section{8}

$\mathrm{B}^{2} 3$ ही

$\cos$

\section{The Effects of Thinning and Similar Stand Treatments on Fire Behavior in Western Forests}

Russell T. Graham, Alan E. Harvey, Threasa B. Jain, and Jonalea R. Tonn 


\section{Preface}

The Interior Columbia Basin Ecosystem Management Project was initiated by the Forest Service and the Bureau of Land Management to respond to several critical issues including, but not limited to, forest and rangeland health, anadromous fish concerns, terrestrial species viability concerns, and the recent decline in traditional commodity flows. The charter given to the project was to develop a scientifically sound, ecosystem-based strategy for managing the lands of the interior Columbia River basin administered by the Forest Service and the Bureau of Land Management. The Science Integration Team was organized to develop a framework for ecosystem management, an assessment of the socioeconomic and biophysical systems in the basin, and an evaluation of alternative management strategies. This paper is one in a series of papers developed as background material for the framework, assessment, or evaluation of alternatives. It provides more detail than was possible to disclose directly in the primary documents.

The Science Integration Team, although organized functionally, worked hard at integrating the approaches, analyses, and conclusions. It is the collective effort of team members that provides depth and understanding to the work of the project. The Science Integration Team leadership included deputy team leaders Russel Graham and Sylvia Arbelbide; landscape ecology - Wendel Hann, Paul Hessburg, and Mark Jensen; aquatic - Jim Sedell, Kris Lee, Danny Lee, Jack Williams, Lynn Decker; economicRichard Haynes, Amy Horne, and Nick Reyna; social science - Jim Burchfield, Steve McCool, Jon Bumstead, and Stewart Allen; terrestrial-Bruce Marcot, Kurt Nelson, John Lehmkuhl, Richard Holthausen, and Randy Hickenbottom; spatial analysis - Becky Gravenmier, John Steffenson, and Andy Wilson.

Thomas M. Quigley

Editor

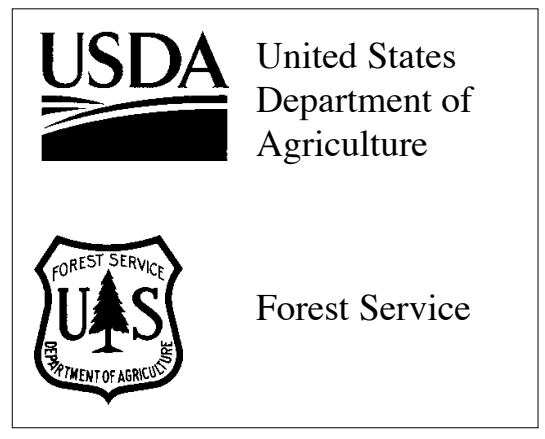

United States
Department of
the Interior

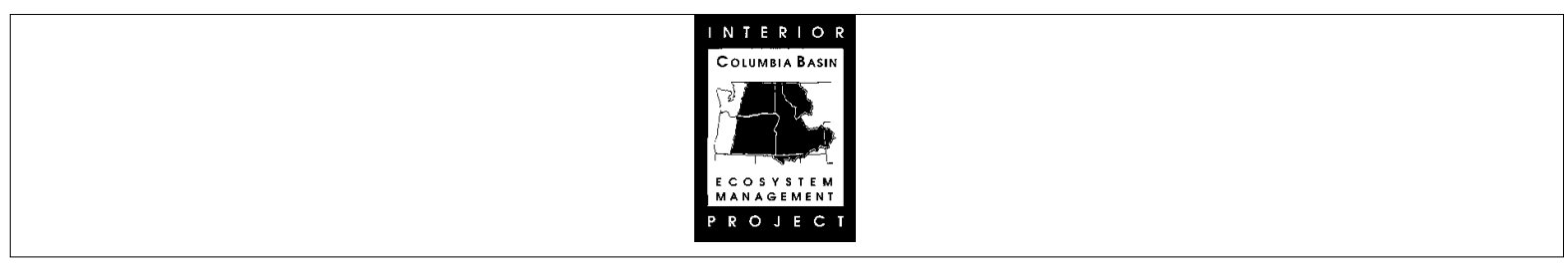

\section{Authors}

RUSSELL T. GRAHAM is a research forester, ALAN E. HARVEY is a research plant pathologist, THERESA B. JAIN is a forester, and JONALEA R. TONN is a forester, Rocky Mountain Research Station, 1221 South Main, Moscow, ID 83843. This paper was prepared in response to issue raised as part of the Interior Columbia Basin Ecosystem Management Project. 
Abstract

Graham, Russell T.; Harvey, Alan E.; Jain, Theresa B.; Tonn, Jonalea R. 1999. The effects of thinning and similar stand treatments on fire behavior in Western forests. Gen. Tech. Rep. PNW-GTR-463. Portland, OR: U.S. Department of Agriculture, Forest Service, Pacific Northwest Research Station. 27 p.

In the West, thinning and partial cuttings are being considered for treating millions of forested acres that are overstocked and prone to wildfire. The objectives of these treatments include tree growth redistribution, tree species regulation, timber harvest, wildlife habitat improvement, and wildfire-hazard reduction. Depending on the forest type and its structure, thinning has both positive and negative impacts on crown fire potential. Crown bulk density, surface fuel, and crown base height are primary stand characteristics that determine crown fire potential. Thinning from below, free thinning, and reserve tree shelterwoods have the greatest opportunity for reducing the risk of crown fire behavior. Selection thinning and crown thinning that maintain multiple crown layers, along with individual tree selection systems, will not reduce the risk of crown fires except in the driest ponderosa pine (Pinus ponderosa Dougl. ex Laws.) forests. Moreover, unless the surface fuels created by using these treatments are themselves treated, intense surface wildfire may result, likely negating positive effects of reducing crown fire potential. No single thinning approach can be applied to reduce the risk of wildfires in the multiple forest types of the West. The best general approach for managing wildfire damage seems to be managing tree density and species composition with well-designed silvicultural systems at a landscape scale that includes a mix of thinning, surface fuel treatments, and prescribed fire with proactive treatment in areas with high risk to wildfire.

Keywords: Silviculture, forest management, prescribed fire, selection, forest fuels, crown fire. 
1 Thinning Methods

3 Thinning

9 Regeneration Methods

12 Resulting Fire Behavior

15 Thinning and Fire Behavior

21 Thinning and Nutrition

22 Conclusion

23 Literature Cited 


\section{Introduction}

\section{Thinning Methods}

Catastrophic wildfire, fire hazard, fire risk, resource damage, and loss of human lives and property are only some of the issues that address the use and occurrence of fires in Western wildlands. Wildfires are common in both forests and rangelands of the West. Over 95 percent of these fires are extinguished when they are small (less than 2 acres). The 2 to 5 percent that are not suppressed burn 95 percent of the area (Dodge 1972). Because of these issues, there is strong sentiment for treating fuel through thinning and prescribed burning to restore wildlands to their former character (Babbitt 1997, Mutch 1994).

Successful fire exclusion over the past 60 to 70 years has contributed to greater stand densities and an increase in crown fire potential in many forests of the West (Mutch 1994). In addition, forests have changed from fire-adapted species to species more susceptible to fire that tend to form unhealthy stands prone to large-scale wildfires, as well as increased outbreaks of insects and diseases (McCool and others 1997). Salvage logging and thinning have been suggested as appropriate preburn treatments before prescribed fire can be safely reintroduced into these dense forests (Mutch and others 1993). Private timber companies demonstrated that thinning and removing diseased and dying trees can lower fire losses to a point where they can reasonably self-insure their tree farms (Schott 1994). In contrast, DellaSala and others (1995) argue that intensive salvage, thinning, and many other logging activities do not reduce the risk of catastrophic fires. Bessie and Johnson (1995) indicate that regional droughts and high winds play a greater role in fire behavior than forest age and fuel loads in high-elevation subalpine fir (Abies lasiocarpa (Hook.) Nutt.) forests. Turner and others (1994) raise doubts about the effectiveness of intensive fuel reductions as "fire-proofing" measures. During the extreme fire season of 1967, however, intensity of fires burning on the Flathead National Forest in western Montana decreased from crown to surface fires when they encountered thinned areas (Cron 1969). In addition to these well-documented and contrasting views on the effect of thinnings on fire behavior, there are many other descriptions, interpretations, and controversies regarding how "thinnings" affect subsequent wildfire or prescribed fire behavior in the "soft" literature. To provide more precise predictive power, the approach we use to address the thinning-fire issue is first to describe forest treatments defined as thinnings, and those that could be interpreted as thinnings, and then show how fires would behave in resulting stand structures, compositions, and fuels created by well-defined treatments. Predictions are based on a variety of literature available for western conifer forests.

Depending on the forest type and biophysical setting, hundreds to tens of thousands of seedlings per acre can naturally regenerate after a disturbance in the inland West (Haig and others 1941, Pearson 1950). Even with such high stand densities, at 100 to 150 years old, only 100 to 200 stems per acre remain (Haig 1932, Meyer 1938). This reduction is caused by intertree competition, wind, snow, ice, diseases, insects, fire, or a combination of these important mortality factors (Haig and others 1941, Oliver and Larson 1990). These stocking reductions allowed the site's growth potential to be concentrated on fewer stems producing fewer but larger trees. The efficiency at which mortality factors reduce the number of stems on a site depends on the disturbance, forest type, and biophysical setting. Individual lodgepole pine (Pinus contorta Dougl. ex Loud.), ponderosa pine (Pinus ponderosa Dougl. ex Laws.), and interior Douglas-fir (Pseudotsuga menziesii (Mirb.) Franco), trees in many areas do 
not readily succumb to intertree competition, often causing stagnated stands with thousands of stems per acre. Likewise, in the mixed-conifer forests of the Cascade Range and northern Rocky Mountains, dense stands of shade-tolerant western hemlock (Tsuga heterophylla (Raf.) Sarg.), grand fir (Abies grandis (Dougl. ex D. Don) Lindl.) and western redcedar (Thuja plicata Donn ex D. Don) are common. Throughout much of the intermountain West, fire was a major mortality factor that thinned stands and selected for fire-resistant species, but fire suppression has aided in the development of large expanses of such dense stands (Hann and others 1997).

Most of the forests dominated by ponderosa pine historically had a large component of large ponderosa pine (Covington and Moore 1994, Hann and others 1997). Because of fire-suppression efforts, the once frequent (20 years or less) low-intensity surface fires no longer clean the forest floor of fine fuels ( 3 inches in diameter or less) and kill patches or individual seedlings and saplings. Resulting forest structures and compositions are now often dominated by many suppressed and intermediate grand firs, white firs (Abies concolor (Gord. \& Glend.) Lindl. ex Hildebr.) and Douglasfirs (Arno 1980, McCool and others 1997). In addition to fire suppression, many of these forests were subjected to the removal of the dominant ponderosa pine through commercial timber harvest (McCool and others 1997).

In addition to natural events that reduce density of forest stands, forest management through application of thinnings also can alter species composition and stand structure. Depending on the objectives, thinnings can be applied to forest stands for various reasons. Classically, thinning is defined as "cuttings made in immature stands in order to stimulate the growth of trees that remain and to increase the total yield of useful material from a stand" (Smith 1962). But, often any kind of partial cutting such as cleaning, weeding, liberation, preparatory, improvement, sanitation, and selection cuttings is termed thinning, especially outside the field of silviculture, and all reduce the number of stems in a forest stand. They could be applied to increase forage for both wildlife and livestock, change tree species composition to create more diseaseand insect-resistant stands, harvest timber products, or alter wildfire behavior. Thinning treatments have the potential to alter fire behavior but, depending on how these intermediate removals are applied, will not necessarily result in compositional or structural changes similar to those produced by nonlethal and mixed-fire disturbances of the native system (Hann and others 1997).

Ground, surface, and crown are the three types of fires most often recognized (Brown and Davis 1973). Surface and crown fires both historically and currently occur in the intermountain West. The intensity (the rate at which fuel is consumed and heat generated) and severity (the damage to both abiotic and biotic forest components) of surface and crown fires depends on species composition, available fuel, fuel arrangement, fuel moisture content, weather, and the physical setting. Depending on how these variables are combined, fires can range from the low-intensity and lowseverity fires that historically occurred in ponderosa pine forests to intense, severe, stand-replacing fires more typical of lodgepole pine or moist, long fire cycle forests. Although stand treatments cannot alter all variables that influence fire behavior, they 
can, directly or indirectly influence species composition, available fuel, fuel arrangement, fuel moisture, and surface winds. Thus, depending on the nature of the thinning, all these factors can be used to change posttreatment wildfire or prescribed fire behavior. To change landscape-scale wildfire behavior and effects, treatments must alter the typically large connected matrix of susceptible patches (stands) that occur in high-risk watersheds (Hann and others 1997, Hessburg and others 1994, Huff and others 1995).

\section{Thinning}

The classic objective of thinning is to redistribute growth potential to fewer trees past the sapling stage, leaving a stand with a desired structure and composition. In general, five methods of thinning are recognized:

1. Low, or thinning from below

2. Crown, or thinning from above

3. Selection, or diameter-limit thinning

4. Free thinning

5. Mechanical thinning (Nyland 1996, Smith and others 1997).

Most often, forest stands do not develop with one canopy. Because of individual tree species, microsite differences, and local disturbances, multiple crown classes usually develop. Four are specifically recognized and used to describe different stand structures (Smith 1962).

Dominant: Trees with crowns extending above the general crown layers receiving full light from above and partly from the sides.

Codominant: Trees with crowns forming the general level of cover and receiving full light from above but comparatively little from the sides.

Intermediate: Trees shorter than the preceding with crowns extending into the crowns formed by dominant and codominants, receiving little direct light from above and none from the sides.

Suppressed: Trees with crowns entirely below the general level of cover, receiving no direct light from above or the sides-overtopped.

These crown classes are used to describe the trees removed in different types of thinnings.

Low thinning (thinning from below) is when trees are removed from the lower canopy, leaving large trees to occupy the site (table 1). This method mimics mortality caused by intertree competition or surface fires and concentrates site growth potential on dominant trees. Low thinnings primarily remove intermediate and suppressed trees, but heavy thinnings also can remove many in the codominant crown class. (fig. 1).

Low thinnings not only remove understory canopies but also can alter species compositions. Usually, different tree species have characteristic development rates that result in individual species dominating specific canopy layers. For example, in many 
Table 1-Trees removed during different intensities of low thinning

\begin{tabular}{ll}
\hline Intensity & Trees removed \\
\hline Very light & Poorest overtopped \\
Light & Overtopped and poorest intermediate \\
Moderate & Overtopped and intermediate \\
Heavy & Overtopped, intermediate, and many codominant
\end{tabular}

Source: Smith 1962.
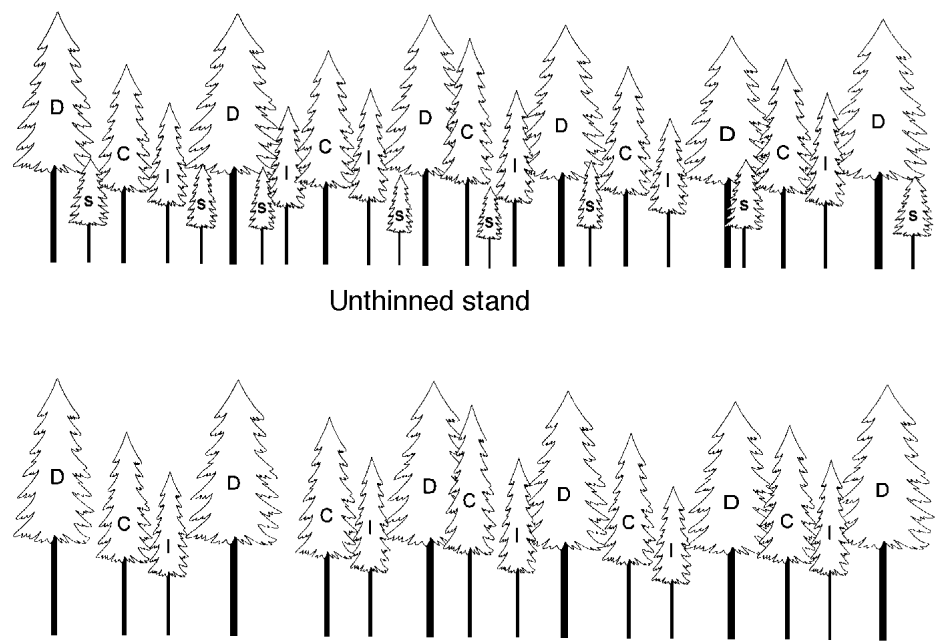

Light thinning

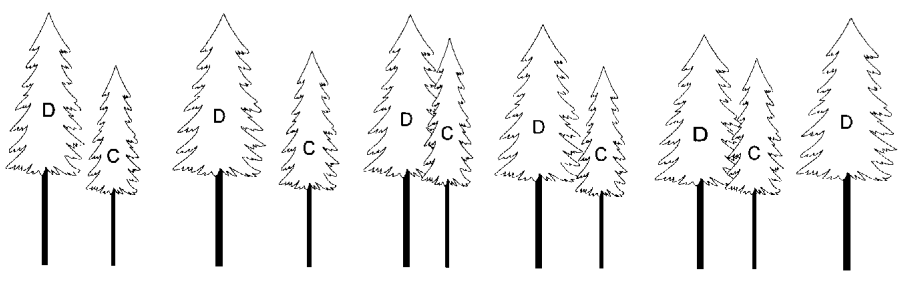

Moderate thinning
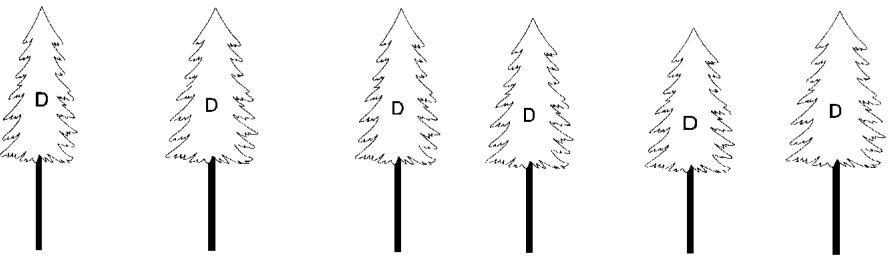

Heavy thinning

Figure 1-A 120-year-old conifer stand containing a mixture of dominant (D), codominant (C), intermediate (I), and suppressed (S) trees thinned from below (low thinning) to three different intensities. 
areas of the West, ponderosa pine primarily occupies the dominant canopy layers, whereas shade-tolerant grand fir, white fir, or Douglas-fir occupy the intermediate and suppressed layers. A low thinning in these stands therefore favors the development of the dominant and codominant ponderosa pine (fig. 1). Depending on the desired stand structure, low thinnings can remove few to many trees. Also, thinnings need not create regular spacings but rather can vary both the number and clumping of residual trees. Low thinnings (thinning from below), therefore, create various stand structures and compositions, depending on the forest type and biophysical setting.

Crown thinning, or thinning from above, reduces crowding within the main canopy. Dominant and codominant trees are removed to favor residual trees in these same classes. This method is often used to remove selected species in the dominant and codominant crown classes that are competing with more desirable species (Nyland 1996). This method keeps vertical structure in place, which is often desirable for wildlife species. Also, intermediate and suppressed shade-tolerant species, such as western redcedar and grand fir, often respond to release if they have adequate crowns (Ferguson and Adams 1980, Graham 1982). As with low thinning, crown thinning can create various stand structures and compositions while retaining vertical structure (fig. 2).

Selection thinning removes dominant trees to favor smaller trees. This method is often applied by removing trees over a certain diameter. Diameter-limit cuts that continually remove the largest trees may well be dysgenetic and can be a disguise for high grading (removing trees of high economic value). By removing the current value from a stand, future options often can be limited, and the only recourse for the future may be to regenerate. Stand structures and species compositions created by using selection thinning are limited and, in general, favor shade-tolerant species or trees occupying the intermediate and suppressed crown classes. Often the stands created by selection thinnings are prone to epidemics of insects and diseases. Compared to the other thinning methods, selection thinning is less useful because of the limited stand structures and compositions it can create (fig. 2).

Free thinning, sometimes called crop-tree thinning, primarily releases selected trees. This method favors specific trees, whereas the remainder of the stand goes untreated. Depending on what is presented in various portions of a stand (tree spacing, species, vertical structure, etc.), the thinning criteria can be highly flexible, producing stands with large amounts of diversity. It can be used in any of the crown classes for releasing specific trees. This method has the most flexibility for creating various stand structures and compositions (fig. 2).

Mechanical thinning removes trees based on specified spatial arrangements (Nyland 1996). This method is often applied in plantations where every other row or every other tree in a row is removed. Such rigid thinning is easy to apply, but the stands created often lack diversity in either structure or composition. This method also resembles strip thinning, where a strip of trees is removed. Mechanical thinning is well suited for timber production on uniform sites but has limited value for producing conditions that meet other resource values. 


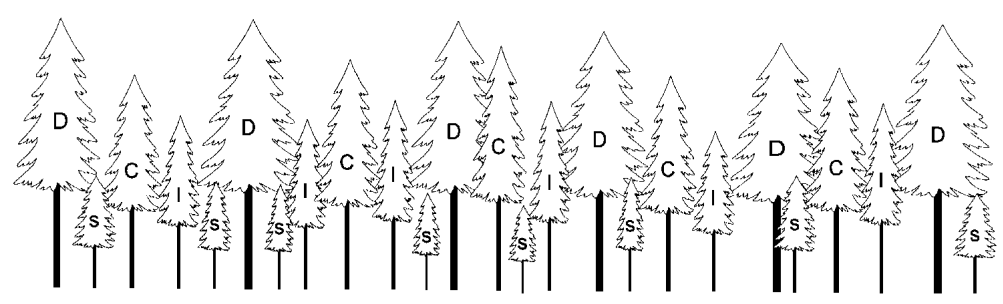

Unthinned stand
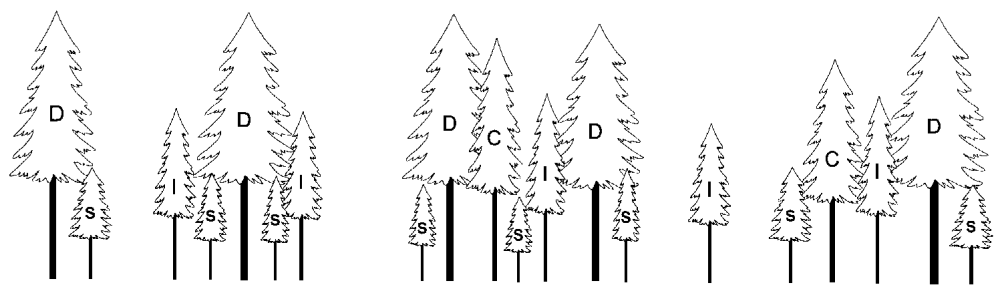

Crown thinning

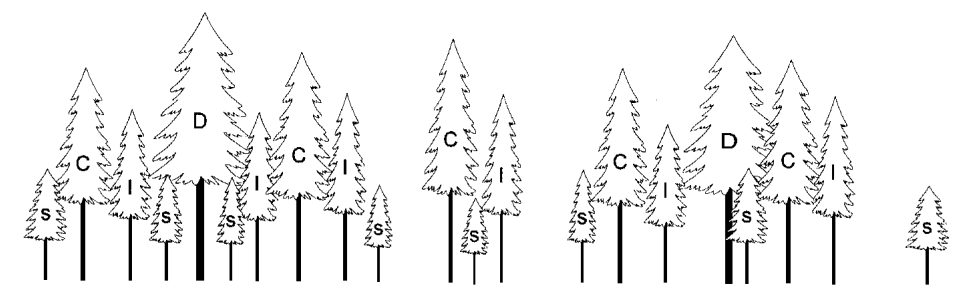

Selection thinning
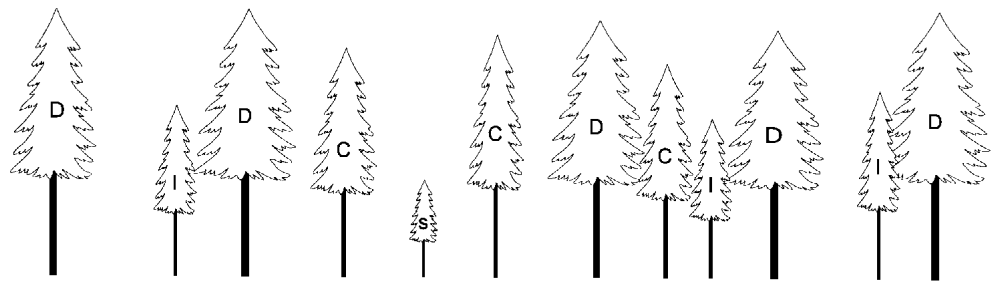

Free thinning

Figure 2-A 120-year-old conifer stand containing a mixture of dominant (D), codominant (C), intermediate (I), and suppressed (S) trees receiving a crown, selection, and free thinning.

Other intermediate treatments often termed "thinning" are types of release cuttings usually applied to sapling-sized trees (fig. 3). These precommercial thinnings usually produce no products with the exception of fencing material or other specialty products. Cleaning usually refers to the removal of one species to favor another. This is often the case where a hardwood (such as quaking aspen, Populus tremuloides Michx. or alder, Alnus spp.) is removed to release a conifer, like western white pine (Pinus monticola Dougl. ex D. Don) or western larch (Larix occidentalis Nutt.).

Weeding can mean releasing conifer seedlings from competing vegetation, or it might 


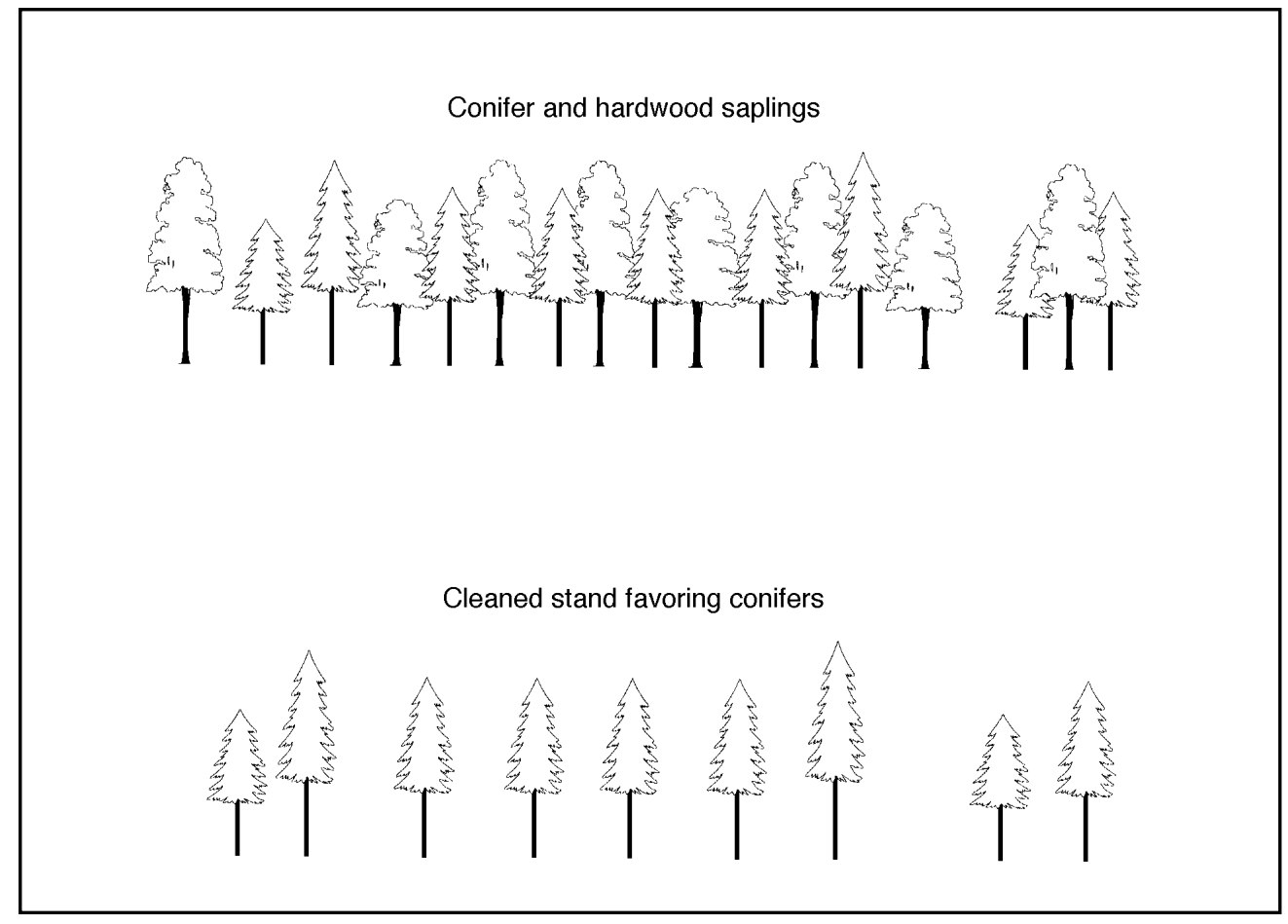

Figure 3-A sapling sized stand of conifers and hardwoods cleaned to favor the conifers.

also denote the removal of vegetation competing with favored trees. Weedings and cleanings mold future stand structure, determining future species composition and individual tree growth.

Liberation cuttings release sapling-sized trees from older, overstory trees (fig. 4). This might occur when planted regeneration or advanced regeneration developing after a wind or ice storm requires protection. The large overstory trees can protect young seedlings from damaging agents early, and then be removed, when saplings no longer need protection. Liberation cuts have limited use for molding different stand structures and compositions. Such cuttings might become more common if reserve seed-tree and shelterwood systems are used to maintain cover while regenerating new stands.

Improvement and salvage cuttings are designed to remove specific, undesirable trees from a stand. Such "sanitation" might remove damaged trees, snags, or trees susceptible to a certain disease or insect. Often this method is used to remove trees damaged by wind or snow, especially if they might encourage the buildup of pests, like Ips spp. Similar to sanitation cuttings, salvage cuttings remove dead or dying 


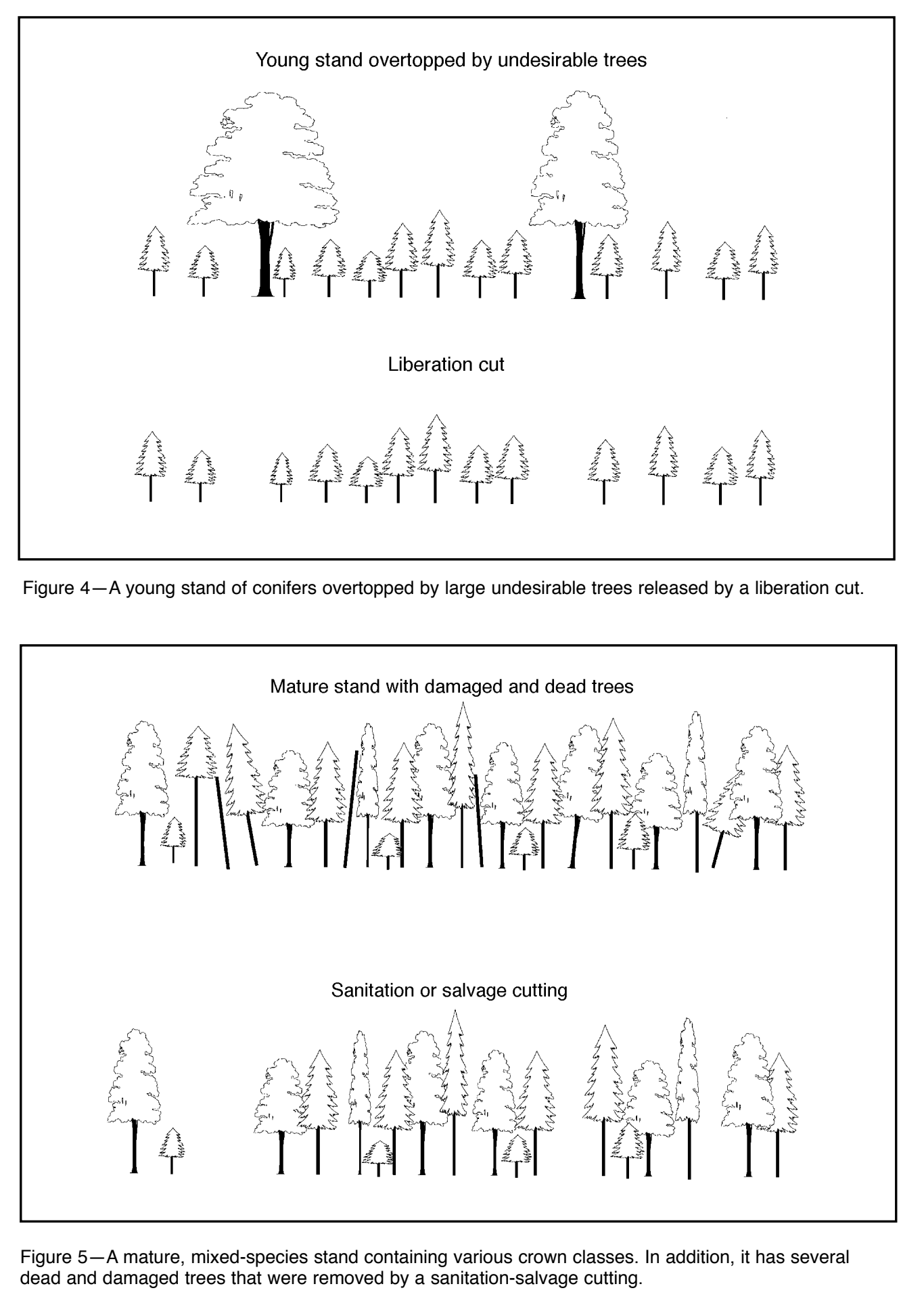


Regeneration Methods trees killed by fire, insects, or disease (fig. 5). Salvage cuttings usually address financial rather than ecological needs (Nyland 1996) even though they are often promoted for restoring drought- and disease-prone forests to more typical mixes of fire-tolerant species (McCool and others 1997). In general, these methods have little impact on overall structure and composition in the short term, but if repeated, they tend to remove value from the stand.

Depending on growth, thinnings to control density can occur several times during the life of a stand. The timing and intensity of each can provide for many different stand structures depending on the management objectives. For example, stocking charts (charts defining tree sizes in a stand at various ages and densities) can be used to determine timing and intensity of intermediate treatments for producing timber (Smith and others 1997). Also, thinning regimes can be designed for producing forest structures desired for wildlife (Reynolds and others 1992). Depending on the forest type, its growth rate and desired stand structure, six or more thinnings might be applied within a 100-year period.

Thinning or other intermediate cuttings are fundamentally methods for controlling stand composition and structure to produce desired forest conditions. Intermediate treatments include all of the above "thinnings." They are intermediate because they occur between the time a stand is regenerated and "final" harvest. Now, more than ever, there is often little distinction between the effects of intermediate treatments and regeneration methods. Under the classic definition of seed-tree and shelterwood regeneration methods, overstory trees are removed once regeneration is secured. But now, because of watershed, wildlife, or scenic values, reserve tree shelterwood and reserve tree seed-tree methods often are used (Reynolds and others 1992). With reserve tree systems, an overstory component is maintained throughout the life of the regenerated stand to provide high forest structure, future snags, and future coarse woody debris. Such reserve systems are often termed irregular shelterwoods, delayed shelterwoods, or extended shelterwoods. Depending on the size, number, spacing, and species of reserve trees, the stands created can easily resemble those maintained by thinnings. This is especially true if preparatory cuts are used in a shelterwood system or the cutting units are small. A preparatory cut removes part of the stand to increase tree vigor, wind firmness, and seed potential. Depending on the intensity of these cuts, they also can resemble thinnings. Also, the reserve trees left in shelterwoods can be grouped and selected by species or size, creating various stand structures (fig. 6).

Stands managed with an individual tree selection system also can resemble thinned stands. The selection system creates and maintains stands with three or more age classes that require multiple entries ranging from 10 to 40 years (Graham 1989, Nyland 1996). In addition to removing trees in the dominant and codominant crown classes, selection systems remove trees in the suppressed and intermediate classes also, so that an uneven-aged, multilayered stand is maintained. Stands managed by using the individual tree system could easily resemble stands thinned by using crown, free, or selection thinnings (fig. 7). As with thinnings, a wide variety of stand 


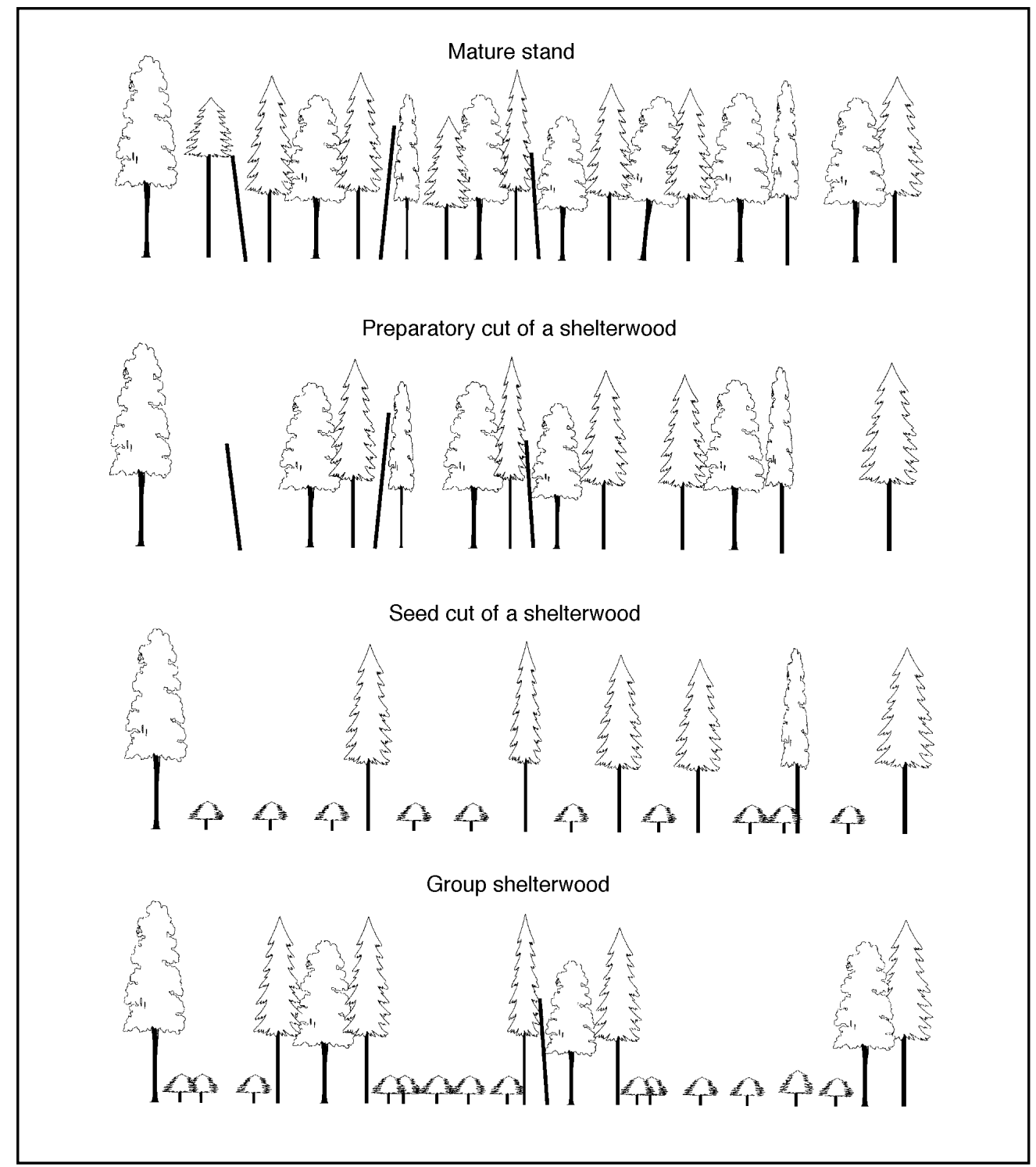

Figure 6-A mature, mixed-species stand regenerated with a shelterwood. A preparatory cut to improve seed production and wind firmness was used before the seed cutting. Also, a group shelterwood is demonstrated. 

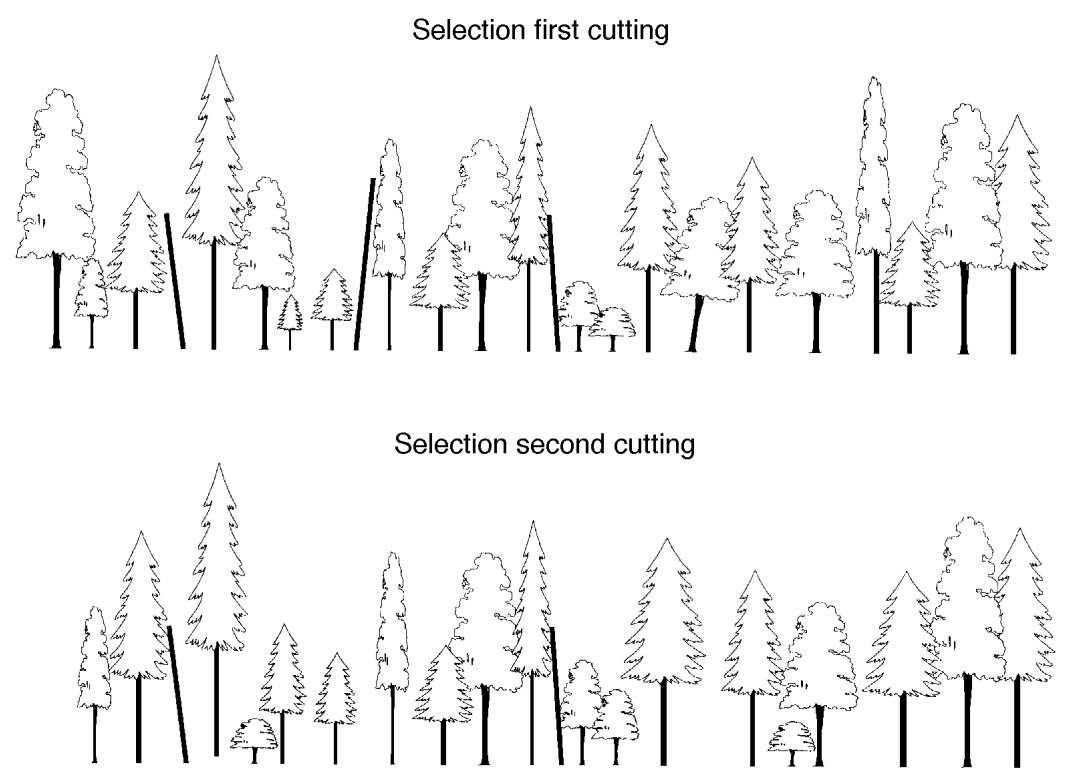

Selection third cutting

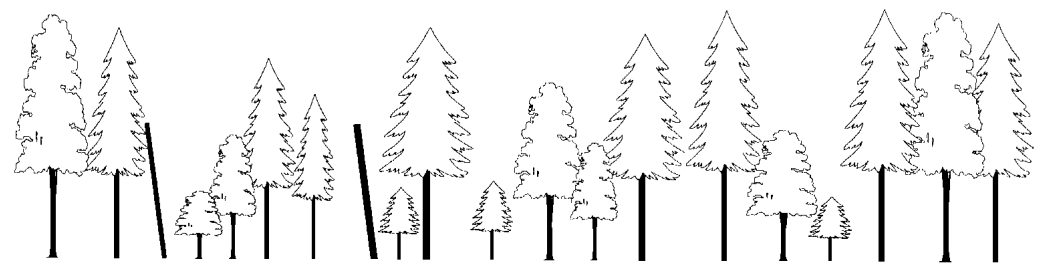

Figure 7-A mixed-species stand managed by using the individual tree selection system on a cutting cycle of 30 years.

structures and compositions can be created. In most cases, the selection system favors development of stands containing shade-tolerant species with high vertical structures. Selective cutting, creaming, culling, high grading, diameter cutting, and maturity selection removals often are termed selection but are actually economic harvests with little or no silvicultural or biological basis (Nyland 1996).

There are many different kinds of thinnings, thinning regimes, reserve tree regeneration methods, and combinations that create a plethora of stand structures and compositions to meet various objectives. Because there is no single method or type of thinning, there is no single structure or composition created by thinnings. Thinning defines a set of intermediate treatments applied to forest stands to create varying 


\section{Resulting Fire Behavior}

compositions and structures, but there are other types of partial cuttings that remove trees. Depending on how a regeneration method (shelterwood, etc.) is applied, it too can create stands with various compositions and structures. If nontraditional regeneration methods, typified by reserve tree shelterwoods, are combined with free thinning or even thinning from below, stands can be created and maintained that meet various management objectives from wildlife habitat improvement to watershed maintenance. Because there are many different stand compositions and structures possible from thinnings and regeneration methods, there are at least as many ways these stands will respond to wildfire or prescribed fire. As mentioned earlier, thinnings can directly or indirectly alter the amount, kind, and moisture of fuel, all key ingredients of future fire behavior.

Fuel models-Fire behavior depends on forest density, composition, amount of surface fuel, its arrangement, moisture content, prevailing weather, and physical setting. To characterize surface fire behavior, 13 fire behavior fuel models are available that describe the fuel complex, fuel loading, fuel bed depth, and moisture of extinction (upper limits of fuel moisture beyond which a fire will no longer spread with a uniform front) in dead and live fuels for grass, shrub, timber, and logging slash groups (Albini 1976) (table 2). These models in combination with dead and live fuel moisture content, slope angle, and wind speed provide a basis for predicting both fire spread rate (chains per hour) and intensity (flame length) (Anderson 1982, Rothermel 1983).

Wind-The standard height for wind measurements used by land management agencies in the United States is 20 feet above the vegetation. All fires in surface fuels burn below the 20-foot height, and because wind is slowed by friction near the surface and overstory vegetation, the 20 -foot wind speed must be adjusted to correctly predict fire behavior near the surface (Rothermel 1983). Depending on the vegetation cover and exposure, 20-foot wind speed reduction factors range from 0.1 to 0.6 to arrive at midflame wind speeds (horizontal wind speed at midflame height) (Albini 1976, Rothermel 1983). For example, the 20-foot wind speed must exceed 50 miles per hour for midflame wind speeds to reach 5 miles per hour within a dense stand ( 0.1 adjustment factor). In contrast, in an open stand ( 0.3 adjustment factor), the same midflame wind speeds would occur at only a 16-mile-per-hour wind at 20 feet.

Crown fire-Surface fire intensity (flame length), crown base height, and moisture content of the live foliage determines crown ignition (Van Wagner 1977). For example, crowns with 75 percent moisture (which might occur in the late fall) and a base height of 10 feet would ignite if flames from a surface fire exceeded 5 feet (Alexander 1988) (fig. 8). Fires this intense (5 feet flame length) would be possible in stands represented by fuel model 10,12 , or 13 when driven by 5 mile per hour midflame winds (table 2). Even though a surface fire might ignite tree crowns, however, the resulting crown fire is not necessarily sustained.

Crown fire spread-Whether crown ignition is sustained or not is determined by rate of spread and crown bulk density (foliage weight in pounds per square foot divided by the average live crown length) (Alexander 1988, Van Wagner 1977). Wind and slope determine potential crown fire spread rate (Rothermel 1991), and species composition and structure control crown bulk density. In general, as crown bulk density 


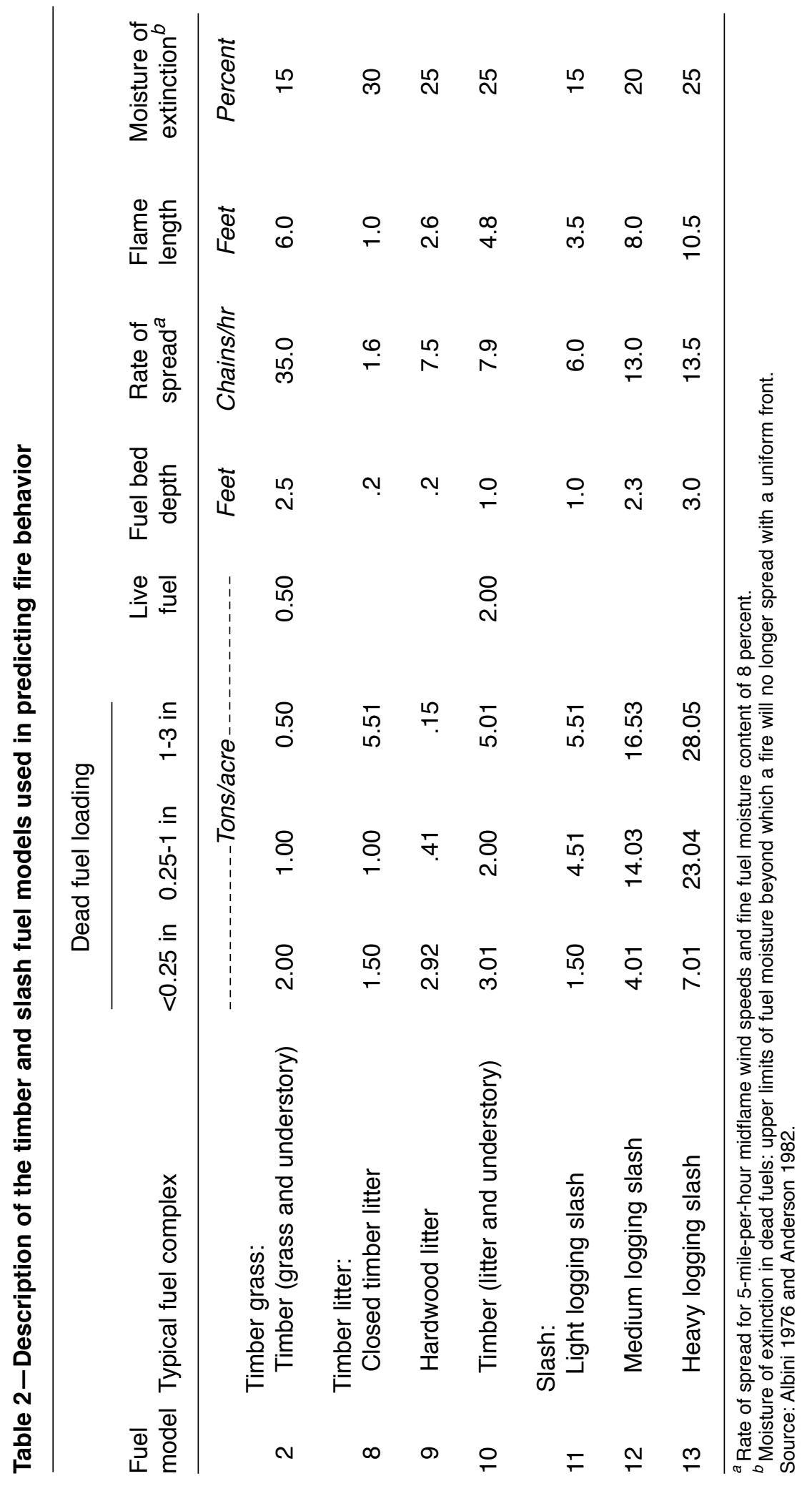




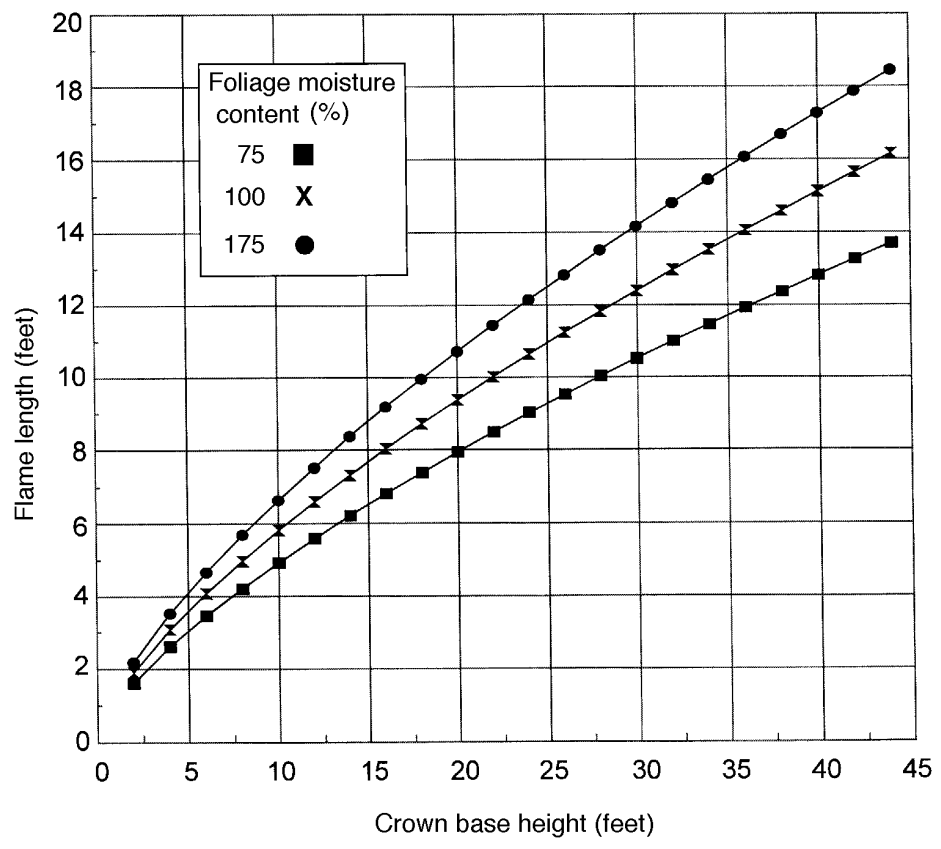

Figure 8-The flame lengths (fire intensities) required to ignite conifer crowns having different base heights for live foliage moisture contents of 75, 100, and 125 percent (Alexander 1988, Van Wagner 1977).

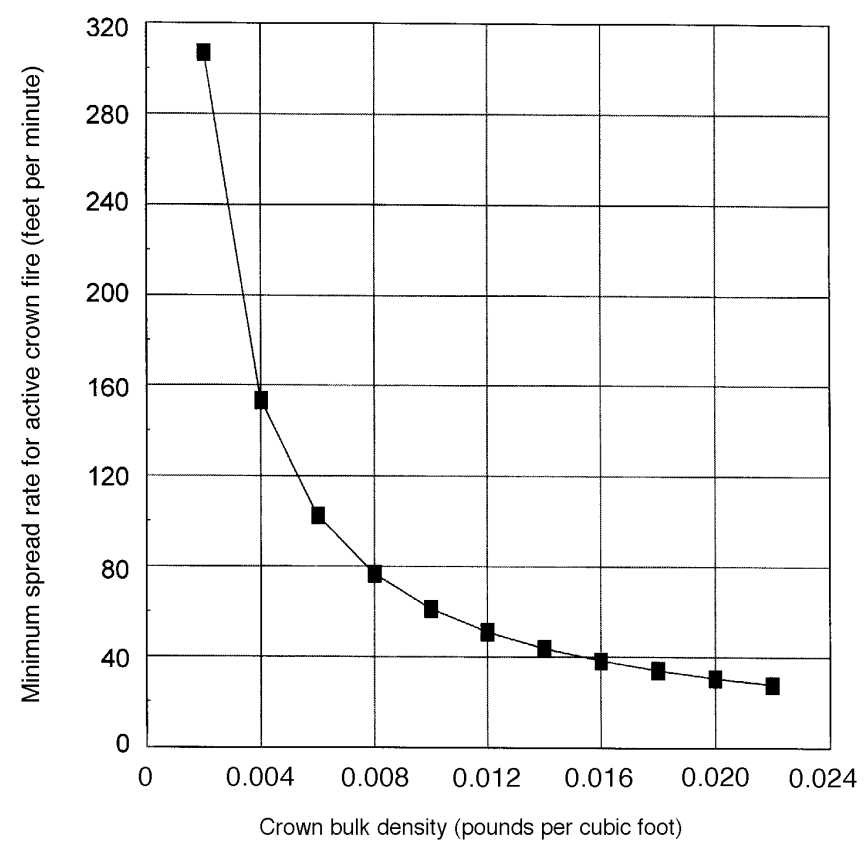

Figure 9-The rate of spread required for crown fires to be sustained as determined by stand crown bulk density (Alexander 1988, Van Wagner 1977). 
Thinning and Fire Behavior

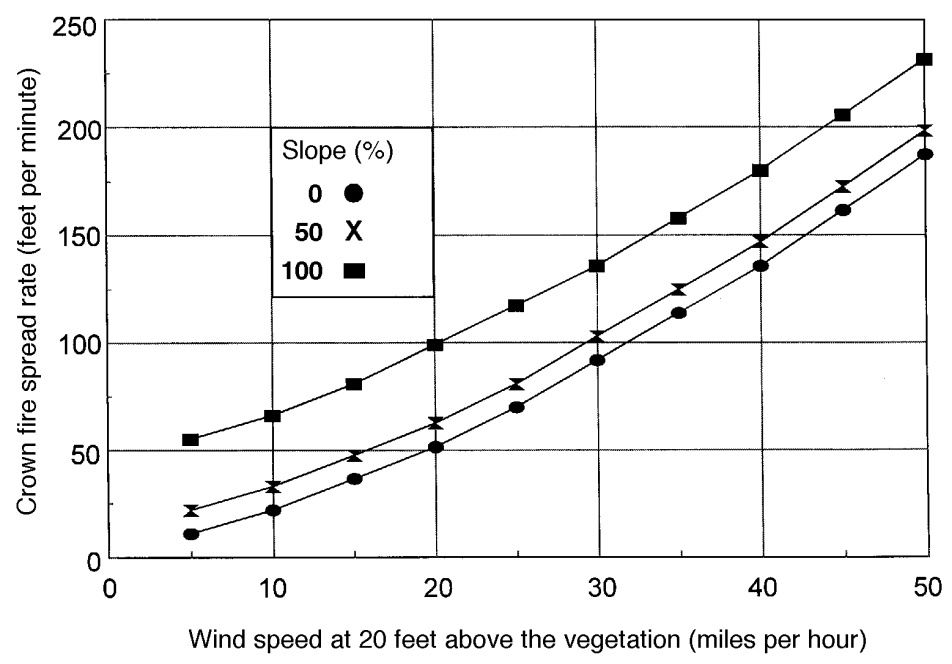

Figure 10-Crown fire spread rates for different slopes and wind speeds. These spread rates are for fires burning in fuel model 10 during a normal summer (Rothermel 1991).

increases, lower rates of spread are required to sustain the fire (fig. 9). For example, during a normal summer, a crown fire burning on a 50-percent slope driven by a 20mile-per-hour wind would spread at about 62 feet per minute (fig. 10). A crown fire would be sustained at those spread rates, except in stands with crown bulk densities less than 0.01 pound per cubic foot (fig. 9). Thus, the primary stand attributes that control a fire's behavior are surface fuel condition, crown bulk density, and crown base height. All three attributes can be directly managed by thinning or other similar forest treatments.

As noted, there are many stand treatments similar to thinnings that may or may not be thinnings. All alter the stand characteristics that directly influence fire behavior. The crowns of trees removed during treatments may significantly contribute to surface fuels (slash). These fuels have a major impact on expected fire intensities depending on whether and how they are treated. The moisture content of surface fuels differs as a function of high forest cover similar to midflame wind speeds. Crown bulk density is the primary controlling factor of crown fire behavior, and it depends on both species composition and stand density. Crown base height also depends on species and growth history (including density and many other stand characteristics that affect crown dimension). Depending on the type, intensity, and extent of thinning, or other treatment applied, fire behavior can be improved (less severe and intense) or exacerbated. 
To show how different stand characteristics affect fire behavior, we assigned specific characteristics to the different stand structures displayed in figures 1-7. In much of the interior Northwest, forests contain mixes of ponderosa pine, Douglas-fir, and grand fir. Often these stands contain dominant and codominant ponderosa pine, grand fir, and Douglas-fir that were historically cleaned by fire. Such stands now, in addition to the dominants and codominants, contain large amounts of ladder fuel (fuel that can carry surface fires into overstory crowns) in the form of intermediate and suppressed fir. These types of stands are displayed in figure 1 and described in table 3. One such hypothetical stand contains 158 trees per acre, has a crown base height of 4 feet, crown bulk density of 0.013 pound per cubic foot, and 12 tons of fuels per acre, 1 foot in depth (fuel model 10, table 2). Crown bulk densities were determined from foliage weights estimated by using Brown's (1978) equations.

In such a stand, if a fire in the surface fuels is driven by 5-mile-per-hour midflame winds, it will produce 5 -foot flames (Anderson 1982) (fuel model 10, table 2). Because the crown base height of the stand is only 4 feet, crown ignition will occur even with crown moisture contents as high as 125 percent (fig. 8). To produce 5-mileper-hour midflame wind speeds, the 20-foot wind speeds in a stand with these densities must exceed 50 miles per hour (Rothermel 1983). Winds of that speed would produce crown fire spread rates over 185 feet per minute, even on flat ground (fig. 10) (Rothermel 1991). A crown fire spread rate of this magnitude would ensure a crown fire is sustained. A crown fire would burn this stand (crown bulk density of 0.013 pound per cubic foot) if spread rates exceeded 46 feet per minute (fig. 9).

Thinning from below - If that stand (fig. 1 and table 3) was moderately thinned from below and all intermediate and suppressed grand fir ladder fuels (small trees in the understory) removed, the crown base height would increase to 40 feet, and the crown bulk density would decrease to 0.006 pound per cubic foot. Further, if the tops and limbs of the cut grand fir were removed and the surface fuel loadings not increased, surface fires would produce 10-foot flames and not ignite the crowns (fuel model 10, table 2). The increased flame lengths in the thinned stand, compared to the unthinned stand, are the result of higher wind speeds that occur in thinned stands. For example, in a closed stand, a 50-mile-per-hour 20-foot wind would create 5-mile-per-hour midflame wind speeds; whereas in a thinned stand, the same midflame wind speeds would be created by just 16- to 25-mile-per-hour 20-foot winds (Rothermel 1983). In contrast, if the cut grand fir were not removed or treated, subsequent fire intensities could ignite the crowns (fig. 8). The increased fire intensities (14-foot flames) would be facilitated by the increased fuel loads (fuel model $12 \mathrm{com}$ pared to fuel model 10) (table 2). Also, dead fuel in the thinned stand would be drier than similar fuels in the unthinned stand (Rothermel 1983).

In the moderately thinned stand (fig. 1, table 3), a crown fire ignited from outside sources (such as a crown fire in an adjoining stand), would cause a sustained crown fire only if spread rates exceeded 100 feet per minute (fig. 9). Stands exhibiting these crown bulk densities ( 0.006 pound per cubic foot) would be relatively protected from crown fires. In our example, the moderate and free thinning would produce these conditions as would the shelterwood cutting (table 3). Such densities would be representative of some common, historical stand structures (fig. 6 and table 3). 
Table 3-Characteristics of a hypothetical mixed ponderosa pine stand about 120 years old growing on a mixed-conifer site with different intermediate treatments and a reserve shelterwood ${ }^{a}$

\begin{tabular}{|c|c|c|c|c|c|c|}
\hline \multirow[b]{2}{*}{ Attribute } & \multicolumn{3}{|c|}{ Uncut stand } & \multicolumn{3}{|c|}{ Light thinning } \\
\hline & D.-fir & G.fir & P.pine & D.-fir & G.fir & P.pine \\
\hline Trees per acre & 8 & 112 & 38 & 8 & 20 & 38 \\
\hline Crown length (ft) & 32 & 10 & 30 & 32 & 18 & 30 \\
\hline Mean height (ft) & 108 & 23 & 81 & 108 & 43 & 81 \\
\hline Crown base height $(\mathrm{ft})^{b}$ & 77 & 4 & 40 & 77 & 25 & 40 \\
\hline Total trees (per acre) ${ }^{c}$ & & & 158 & & & 66 \\
\hline \multirow[t]{2}{*}{ Crown bulk density $(\mathrm{lb} / \mathrm{ft})^{c}$} & & & 0.013 & & & 0.007 \\
\hline & \multicolumn{3}{|c|}{--Moderate thinning-- } & \multicolumn{3}{|c|}{-- Heavy thinning ---} \\
\hline Trees per acre & 8 & 0 & 38 & 6 & 0 & 30 \\
\hline Crown length (ft) & 32 & -- & 30 & 33 & -- & 32 \\
\hline Mean height (ft) & 108 & -- & 81 & 103 & -- & 82 \\
\hline Crown base height (ft) ${ }^{b}$ & 77 & -- & 40 & 71 & -- & 50 \\
\hline Total trees (per acre) ${ }^{c}$ & & & 46 & & & 36 \\
\hline \multirow[t]{2}{*}{ Crown bulk density $(\mathrm{lb} / \mathrm{ft})^{c}$} & & & 0.006 & & & 0.005 \\
\hline & \multicolumn{3}{|c|}{--- Crown thinning---- } & \multicolumn{3}{|c|}{----Free thinning--- } \\
\hline Trees per acre & 4 & 108 & 30 & 6 & 23 & 30 \\
\hline Crown length (ft) & 29 & 9 & 32 & 31 & 19 & 32 \\
\hline Mean height (ft) & 104 & 23 & 82 & 111 & 52 & 83 \\
\hline Crown base height (ft) ${ }^{b}$ & 75 & 4 & 51 & 80 & 33 & 51 \\
\hline Total trees (per acre) ${ }^{c}$ & & & 142 & & & 59 \\
\hline \multirow[t]{2}{*}{ Crown bulk density $(\mathrm{lb} / \mathrm{ft})^{C}$} & & & 0.010 & & & 0.006 \\
\hline & \multicolumn{3}{|c|}{--Selection thinning-- } & \multicolumn{3}{|c|}{-----Shelterwood--- - } \\
\hline Trees per acre & 3 & 112 & 19 & 0 & 0 & 15 \\
\hline Crown length (ft) & 29 & 12 & 28 & -- & -- & 35 \\
\hline Mean height (ft) & 102 & 26 & 84 & -- & -- & 84 \\
\hline Crown base height $(\mathrm{ft})^{b}$ & 73 & 4 & 49 & -- & -- & 49 \\
\hline Total trees (per acre) ${ }^{c}$ & & & 134 & & & 15 \\
\hline Crown bulk density $(\mathrm{lb} / \mathrm{ft})^{c}$ & & & 0.007 & & & 0.002 \\
\hline
\end{tabular}

\footnotetext{
${ }^{a}$ These characteristics describe the stands displayed in figures 1,2, and 6 .

${ }^{b}$ The lowest crown base height that occurs in the stand is the value assigned to the entire stand.

${ }^{c}$ Total trees per acre and crown bulk density are values for the entire stand.
} 
Thinnings in general will lower crown bulk densities and redistribute fuel loads significantly, thus decreasing fire intensities if the surface fuels are treated (Agee 1993, Alexander 1988, Alexander and Yancik 1977). These removals have been shown to be effective in reducing crown fire potential, especially around homes (Coulter 1980, Dennis 1983, Rothermel 1991, Schmidt and Wakimoto 1988). Because of drier fuels (fuels are more exposed to wind and heat) and increased wind speeds that occur in thinned stands, it is critical that they be treated to minimize fire intensity. In California, plantations where surface fuels were treated had substantially less damage from wildfires compared to untreated plantations that burned completely and severely (Weatherspoon and Skinner 1995).

Species composition-By using the same characteristics to describe a mixed stand of grand fir, Douglas-fir, and western white pine, the crown bulk density is 0.006 pound per cubic foot compared to 0.013 pound per cubic foot for the stand dominated by ponderosa pine (table 4). To sustain a crown fire in this uncut western white pine stand, a spread rate of 100 feet per minute would be required to sustain a crown fire compared to only a 46-feet-per-minute rate of spread required for sustaining a crown fire in the ponderosa pine stand (fig. 9). If the stand was dominated by western larch instead of western white pine, however, it would have even lower crown bulk densities (Brown 1978, Rothermel 1983). Thus, crown fires would be more difficult to sustain in western white pine- and western larch-dominated stands than in stands dominated by other species.

A western white pine stand heavily thinned from below by removing the grand fir, and some codominant trees to a density of 36 trees per acre would result in a stand crown bulk density of 0.002 pound per cubic foot (table 4). A crown fire spread rate of 300 feet per minute would be required for a fire to be sustained, effectively removing the crown fire threat from these stands (fig. 9). These low crown bulk densities are the result of western white pine crowns that tend to be narrower and shorter than crowns of most of its associates, with the exception of western larch.

All methods of thinning could reduce the number of trees to a point where crown fires would be difficult to initiate or sustain, but these conditions may not meet many present multiresource values. Because crown thinning and selection thinnings leave suppressed and intermediate trees, crown base heights remain low and crown bulk densities could remain high thus not decreasing the potential for crown fire (tables 3 and 4, fig. 2). In contrast, free thinning, could be effective at decreasing crown fire risk depending on thinning intensity. But the stand treated by using free thinning in our example would still be prone to crown fire initiation and spread (tables 3 and 4 , fig. 2).

Other immediate treatments-Sanitation and salvage harvests would do little to minimize crown fire initiation or spread because crown bulk densities would likely always exceed 0.006 pound per cubic foot (fig. 5). Likewise, ladder fuels and low crown base heights would exist in most stands receiving salvage cuttings. Thus salvage and sanitation harvests would probably not significantly change the potential fire characteristics even if the surface fuels were treated. 
Table 4-The characteristics of a hypothetical mixed western white pine stand about 120 years old growing on a mixed-conifer site with different intermediate treatments and a reserve shelterwood ${ }^{a}$

\begin{tabular}{|c|c|c|c|c|c|c|}
\hline \multirow[b]{2}{*}{ Attribute } & \multicolumn{3}{|c|}{ Uncut stand } & \multicolumn{3}{|c|}{ Light thinning } \\
\hline & D.-fir & G.fir & P.pine & D.-fir & G.fir & P.pine \\
\hline Trees per acre & 8 & 112 & 38 & 8 & 20 & 38 \\
\hline Crown length (ft) & 32 & 10 & 33 & 32 & 18 & 33 \\
\hline Mean height (ft) & 108 & 23 & 130 & 108 & 43 & 130 \\
\hline Crown base height (ft) ${ }^{b}$ & 77 & 4 & 97 & 77 & 25 & 97 \\
\hline Total trees (per acre) ${ }^{c}$ & & & 158 & & & 66 \\
\hline \multirow[t]{2}{*}{ Crown bulk density $(\mathrm{lb} / \mathrm{ft})^{c}$} & & & 0.006 & & & 0.003 \\
\hline & \multicolumn{3}{|c|}{--Moderate thinning-- } & \multicolumn{3}{|c|}{--- Heavy thinning--- } \\
\hline Trees per acre & 8 & 0 & 38 & 6 & 0 & 30 \\
\hline Crown length (ft) & 32 & -- & 33 & 32 & -- & 36 \\
\hline Mean height $(\mathrm{ft})$ & 108 & -- & 130 & 103 & -- & 136 \\
\hline Crown base height $(\mathrm{ft})^{b}$ & 77 & -- & 97 & 71 & -- & 100 \\
\hline Total trees (per acre) ${ }^{c}$ & & & 46 & & & 36 \\
\hline \multirow[t]{2}{*}{ Crown bulk density $(\mathrm{lb} / \mathrm{ft})^{C}$} & & & 0.003 & & & 0.002 \\
\hline & \multicolumn{3}{|c|}{--- Crown thinning --- } & \multicolumn{3}{|c|}{--- Free thinning---- } \\
\hline Trees per acre & 4 & 108 & 30 & 6 & 23 & 30 \\
\hline Crown length (ft) & 29 & 9 & 31 & 31 & 19 & 36 \\
\hline Mean height (ft) & 108 & 23 & 125 & 111 & 52 & 136 \\
\hline Crown base height (ft) ${ }^{b}$ & 75 & 4 & 94 & 80 & 33 & 100 \\
\hline Total trees (per acre) ${ }^{c}$ & & & 142 & & & 59 \\
\hline \multirow[t]{2}{*}{ Crown bulk density $(\mathrm{lb} / \mathrm{ft})^{c}$} & & & 0.004 & & & 0.002 \\
\hline & \multicolumn{3}{|c|}{ - Selection thinning-- } & \multicolumn{3}{|c|}{--- Shelterwood } \\
\hline Trees per acre & 3 & 112 & 19 & 0 & 0 & 15 \\
\hline Crown length (ft) & 29 & 12 & 27 & -- & -- & 39 \\
\hline Mean height (ft) & 102 & 26 & 115 & -- & -- & 147 \\
\hline Total trees (per acre) ${ }^{C}$ & & & 134 & & & 15 \\
\hline Crown bulk density $(\mathrm{lb} / \mathrm{ft})^{C}$ & & & 0.003 & & & 0.001 \\
\hline
\end{tabular}

${ }^{a}$ These characteristics describe the stands displayed in figures 1, 2, and 6 .

${ }^{b}$ The lowest crown base height that occurs in the stand is the value assigned to the entire stand.

${ }^{c}$ Total trees per acre and crown bulk density are values for the entire stand. 
Cleanings and weedings (precommercial thinnings) in sapling-sized stands can influence fire behavior by favoring species with light crowns (western larch and western white pine). In addition, cleaning plantations by removing brush has successfully reduced damage from wildfires in California (Van Wagner 1968). These treatments can space trees, allowing stands with low crown bulk densities to develop.

Precommercial thinnings to reduce either competition or favor ponderosa pine over Douglas-fir or grand fir in dry ecosystems generally seems likely to improve the health of these forests; the situation in moist forests may be more demanding. Moist forests evolved as dense stands largely dominated by seral species, especially western white pine and western larch. Native pest actions and periodic fire "thinned" late seral species (grand fir, white fir, western hemlock, and western redcedar) continuously over time. In the absence of a significant component of western white pine and western larch, simple thinning of a late seral stand to reduce competition or crown bulk densities may not decrease activities of insects and pathogens or select appropriate genotypes, either of which could offset any reduction in crown fire potential within a relatively short time. Thus, thinning in moist forests should be approached carefully. Any approach to reduce crown fire potential and improve health should be tied to the active restoration of early seral species, especially the western white pine and western larch. Precommercial thinnings not only mold a stand's future composition and structure but usually produce large quantities of fine fuels. Fuel models 12 and 13, with over 30 tons per acre of fuel, often are used to describe the slash created by precommercial thinnings (table 2) (Anderson 1982).

Fire intensity in thinned stands is greatly reduced if thinning is accompanied by reducing the surface fuels created by the cuttings. Fire has been successfully used to treat fuels and decrease the effects of wildfires especially in climax ponderosa pine forests (Deeming 1990; Wagel and Eakle 1979; Weaver 1955, 1957). In contrast, extensive amounts of untreated logging slash contributed to the devastating fires during the late 1800 s and early 1900 s in the inland and Pacific Northwest forests. These catastrophic fires led to both laws and policies governing the treating of slash after timber harvesting (Brown and Davis 1973, Deeming 1990). These initiatives led to several methods, in addition to fire, for treating fuels including cutting, scattering, piling, clearing, crushing, and disking (Brown and Davis 1973).

Silvicultural systems-A series of forest treatments or a silvicultural system that maintains multiple forest canopies and high crown bulk densities is unlikely to decrease the potential for crown fire behavior. Individual tree selection systems that remove and tend trees on cutting cycles of 10 to 40 years will likely maintain stands prone to crown fire behavior (fig. 7). (Pure, climax stands of ponderosa pine would be the exception.) In mixed-conifer stands, crown bulk densities would remain high, crown base heights would be low, and fine fuels would be continually generated. In addition, these silvicultural systems favor the development of stands dominated by grand fir, western hemlock, or other shade-tolerant species (Graham 1989, Nyland 1996). These species all tend to have long and heavy crowns creating stands with high bulk densities (Brown 1978, Rothermel 1983).

Seed-tree and shelterwood regeneration methods and all of their variations have the potential to reduce the severity and intensity of wildfires. Open stands with low crown bulk densities would not likely support a crown fire when the regeneration was short 


\section{Thinning and Nutrition}

(fig. 6, tables 3 and 4). But if the regeneration was not precommercially thinned, the subsequent development of ladder fuels would increase potential for crown fire behavior. The stand structures created by group shelterwoods would likely be prone to crown fire behavior depending on the density and spacing of the groups of leave trees (fig. 6).

Opinions differ as to the relative threat of changes in inland forests this century, but there is general agreement that changes have occurred (Baker 1988, Brown 1983). In general, there has been a shift from open ponderosa pine to closed pine and Douglas-fir stands in dry ecosystems, and in moist forests, the change has been from tall western white pine-western larch stands to relatively short, closed grand firwestern hemlock-western redcedar stands (Harvey and others 1994, Mutch and others 1993). These shifts toward late-successional species occurred relatively rapidly, compressing successional processes. In dry ecosystems with historically frequent fire regimes, ponderosa pine may not be succeeded by Douglas-fir in 300 to 400 years, but it has occurred in only 40 years in some locations in southern Idaho (Harvey and others 1994). Similarly, in western white pine-dominated ecosystems with mixed and variable fire regimes, early seral species may (or may not, depending on fire frequency) be succeeded by late seral species in 200 to 300 years. In the Coeur d'Alene Mountains in northern Idaho, however this conversion took less than 50 years (Moeur 1992).

These changes have altered the nutrient dynamics that historically occurred in the forests of the inland West. Ponderosa pine, western white pine, and western larch all tend to be tall and self-prune, even in moderately dense stands. In addition, the crowns of western white pine and western larch have low bulk densities and nutrient content compared to most late-successional species (Minore 1979). These species in general carry their canopies well above the surface fuels, do not carry crown fires well, and tend not to have ladder fuels. Thus canopy nutrient stores are relatively well protected from fire. In contrast, stands dominated by the true firs, Douglas-fir, western hemlock, and western redcedar do not self-prune well, carry large branches low in the canopy, and have relatively high crown bulk densities with resulting high nutrient concentrations (Brown 1978, Minore 1979). Stands dominated by these species usually support crown fires well and have generally high nutrient content in tissues susceptible to loss from fire.

Pines and western larch tend to be deep rooted, whereas the true firs, western hemlock, and western redcedar all tend to be relatively shallow rooted with large numbers of fine roots in the high nutrient content, shallow soil organic layers (Harvey and others 1986, Minore 1979). Douglas-fir also shows this trend when compared to ponderosa pine. Thus the nutrients and nutrient turnover tend to be dispersed vertically in soils dominated by early seral species and concentrated near the surface when the stand is dominated by late seral species. Soil surface nutrient stores and feeder roots in late seral species-dominated stands (or early seral stands if surface organics accumulate from fire exclusion) can be at more risk to wildfire, or other disturbance, than the historic pine and western larch-dominated stands. Therefore, the combination of dense, heavy, nutrient-rich crowns and roots and nutrients concentrated in the surface layers make stands dominated by late seral species at much higher 
risk to long-term nutrient losses from wildfire and other disturbances than stands dominated by early seral species. Tree removal from thinnings can also significantly alter nutrient storage and turnover in the modified stands. For example, any treatment that removes large quantities of branches and needles has the potential to reduce onsite nutrient reserves. As much as 45 percent of site potassium and 25 percent of site nitrogen stores can be contained in branchwood, needles, and other similar materials (Jurgensen and others 1997, Moore 1994). If the site is chronically short on these nutrients, as many are, intensive removal of these materials is likely to cause subsequent nutrient shortage. On the other hand, with potentially volatile nutrients like nitrogen and sulfur, high-intensity fire can bring about even greater losses, especially with nitrogen (Jurgensen and others 1997). Similarly, on low-fertility situations (especially dry sites) where soil organic horizons and coarse woody debris supplies may be low, both intense fire or overzealous removal of fuel to prevent fire can imperil future site productivity. In most cases where sites are fragile from a nutrient standpoint, leaving "fines" on the site for even one winter can redistribute nutrients, including nitrogen, potassium and sulfur, downward into the soil (Harvey and others 1987, Larsen and others 1981, Moore 1994). This downward movement can provide significant protection from volatilization by fire or physical removal as a fire-modification treatment (Mroz and others 1978). Thus, balancing relative risks with nutrient and organic matter site legacies is an important aspect of any fuel-management operation.

\section{Conclusion}

Thinning and other thinning-like stand treatments can substantially influence subsequent fire behavior at the stand level by either increasing or decreasing fire intensity and associated severity of effects. Depending on intensity, thinning from below and possibly free thinning can most effectively alter fire behavior by reducing crown bulk density, increasing crown base height, and changing species composition to lighter crowned and fire-adapted species. Such intermediate treatments can reduce the severity and intensity of wildfires for a given set of physical and weather variables. But crown and selection thinnings would not reduce crown fire potential. Similarly, because multiple canopy layers, and shade-tolerant species are favored in stands where an individual tree selection system is used, crown fire potential would be high. A possible exception is in the driest of the ponderosa pine forests where low crown densities can be achieved by using the selection system.

Salvage and sanitation cuttings would not decrease potential for crown fire behavior unless tree densities were substantially reduced. Stand densities would need to be similar to the moderately and heavily thinned stands displayed in our examples to "fire-proof" a stand. In all cases, any intermediate treatment needs to be accompanied by surface fuel modification. If the fine fuels are removed after a winter or burned with a low-intensity prescribed fire, there is minimal loss of nutrients. The best success in modifying fire behavior through the use of thinnings throughout the West is when applied in conjunction with prescribed fire. In climax ponderosa pine forests, cleaning stands with prescribed fire has been effective in modifying wildfire behavior. 


\section{Literature Cited}

Silvicultural systems can be designed to manage forest stands to reduce crown fire potential. But in doing so, other characteristics such as vertical structure or species diversity may be altered. No single thinning or management prescription, therefore, will achieve multiresource objectives across all stands within a landscape. By understanding stand characteristics that affect prescribed and wildfire fire behavior, forest landscapes can be designed that minimize potential for severe fire effects or crown fire behavior. Silvicultural systems using density and species management, along with the judicial use of prescribed fire, are key to managing Western forests.

Agee, James K. 1993. Fire ecology of Pacific Northwest forests. Washington, DC: Island Press. 493. p.

Albini, Frank A. 1976. Estimating wildfire behavior and effects. Gen. Tech. Rep. INT30. Ogden, UT: U.S. Department of Agriculture, Forest Service, Intermountain Forest and Range Experiment Station. $92 \mathrm{p}$.

Alexander, Martin E. 1988. Help with making crown fire assessments. In: Fischer, William C.; Arno, Stephen F., comps. Protecting people and homes from wildfire in the interior West: Proceedings of the symposium and workshop; 1987 October 6-8; Missoula, MT. Gen. Tech. Rep. INT-251. Ogden, UT: U.S. Department of Agriculture, Forest Service, Intermountain Forest and Range Experiment Station: 147-156.

Alexander, Martin E.; Yancik, Richard F. 1977. The effect of precommercial thinning on fire potential in a lodgepole stand. Fire Management Notes. 38(3): 7-9.

Anderson, Hal E. 1982. Aids to determining fuels models for estimating fire behavior. Gen. Tech. Rep. INT-122. Ogden, UT: U.S. Department of Agriculture, Forest Service, Intermountain Forest and Range Experiment Station. 22 p.

Arno, S.F. 1980. Forest fire history in the northern Rockies. Journal of Forestry. 78: 460-465.

Babbitt, Bruce. 1997. A coordinated campaign: fight fire with fire. Remarks of Secretary of the Interior, Bruce Babbitt. February 11, 1997. On file with: Boise State University, Boise, ID 83725.

Baker, W.L. 1988. Effects of settlement and fire suppression on landscape structure. Ecology. 159: 133-140.

Bessie, W.C.; Johnson, E.A. 1995. The relative importance of fuels and weather on fire behavior in subalpine forests. Ecology. 76: 747-762.

Brown, A.A.; Davis, K.P. 1973. Forest fire: control and use. New York: McGraw-Hill. $686 \mathrm{p}$.

Brown, J.K. 1978. Weight and density of crowns of Rocky Mountain conifers. Res. Pap. INT-197. Ogden, UT: U.S. Department of Agriculture, Forest Service, Intermountain Forest and Range Experiment Station. 56 p. 
Brown, J.K. 1983. The "unnatural fuel buildup" issue. In: Lotan, J.E.; Kilgore, B.M.; Fischer, W.C. [and others], coords. Proceedings, symposium and workshop on wilderness fire; 1983 November 15-18; Missoula, MT. Gen. Tech. Rep. INT-128. Ogden, UT: U.S. Department of Agriculture, Forest Service, Intermountain Forest and Range Experiment Station: 127-128.

Coulter, Bruce J. 1980. Wildfire safety guidelines for rural home owners. Fort Collins, CO: Colorado State Forest Service, Colorado State University. 23 p.

Covington, W.W.; Moore, M.M. 1994. Postsettlement changes in natural fire regimes and forest structure: ecological restoration of old-growth ponderosa pine forests. In: Sampson, R. Neil; Adams, David L., eds. Assessing forest ecosystem health in the inland West. New York: The Haworth Press Inc: 153-181.

Cron, Robert H. 1969. Thinning as an aid to fire control. Fire Control Notes. 30(1).

Deeming, John E. 1990. Effects of prescribed fire on wildfire occurrence and severity. In: Walstead, John D.; Radosevich, Steven R.; Sandberg, David V., eds. Natural and prescribed fire in Pacific Northwest Forests. Corvallis, OR: Oregon State University Press: 95-104.

DellaSala, Dominick A.; Olson, David M.; Barth, Sara E. [and others]. 1995. Forest health: moving beyond rhetoric to restore healthy landscapes in the inland Northwest. Wildlife Society Bulletin. 23(3): 346-356.

Dennis, Frank C. 1983. Fuel break guidelines for forested subdivisions. Fort Collins, CO: Colorado State Forest Service, Colorado State University. 16 p.

Dodge, Marvin. 1972. Forest fuel accumulation. Science. 177: 139-142.

Ferguson, D.E.; Adams, D.L. 1980. Response of advance grand fir regeneration to overstory removal in northern Idaho. Forest Science. 26: 537-545.

Graham, R.T. 1982. Influence of tree and site factors on western redcedar's response to release: a modeling analysis. Res. Pap. INT-296. Ogden, UT: U.S. Department of Agriculture, Forest Service, Intermountain Forest and Range Experiment Station. $19 \mathrm{p}$.

Graham, R.T. 1989. Uneven-aged management in the northern Rocky Mountains. In: Proceedings, national silviculture workshop: silviculture for all resources; 1987 May 11-14; Sacramento, CA. Washington, DC: U.S. Department of Agriculture, Forest Service, Timber Management: 290-297.

Haig, I.T. 1932. Second-growth yield, stand, and volume tables for western white pine type. Tech. Bull. 323. Washington, DC: U.S. Department of Agriculture. 68 p.

Haig, I.T.; Davis, K.P.; Weidman, R.H. 1941. Natural regeneration in the western white pine type. Tech. Bull. 767. Washington, DC: U.S. Department of Agriculture. $99 \mathrm{p}$. 
Hann, Wendel J.; Jones, Jeffrey L.; Karl, Michael G. "Sherm" [and others]. 1997. Landscape dynamics of the basin. In: Quigley, Thomas M.; Arbelbide, Sylvia J., tech. eds. An assessment of ecosystem components in the interior Columbia basin and portions of the Klamath and Great Basins: Gen. Tech. Rep. PNW-GTR405. Portland, OR: U.S. Department of Agriculture, Forest Service, Pacific Northwest Research Station: 338-1055. Chapter 3. 2 vol.

Harvey, A.E.; Hessburg, P.F.; Byler, J.W. [and others]. 1994. Health declines in interior forests: symptoms and solutions. In: Baumgartner, D.M.; Everett, R., coords. Ecosystem management in Western interior forests. Pullman, WA: Washington State University, Cooperative Extension: 163-170.

Harvey, A.E.; Jurgensen, M.F.; Larsen, M.J. 1987. Residues, beneficial microbes, diseases, and soil management in cold, east slope, Rocky Mountain lodgepole pine ecosystems. In: Management of small-stem stands of lodgepole pine-work shop proceedings. Gen. Tech. Rep. INT-237. Ogden, UT: U.S. Department of Agriculture, Forest Service, Intermountain Forest and Range Experiment Station: 137-149.

Harvey, A.E.; Jurgensen, M.F.; Larsen, M.J.; Schlieter, J.A. 1986. Distribution of active ectomycorrhizal short roots in forest soils of the inland Northwest: effects of site and disturbance. Res. Pap. INT-374. Ogden, UT: U.S. Department of Agriculture, Forest Service, Intermountain Research Station. 8 p.

Hessburg, P.F.; Mitchell, R.G.; Filip, G.M. 1994. Historical and current roles of insects and pathogens in eastern Oregon and Washington forested landscapes. Gen. Tech. Rep. PNW-GTR-327. Portland, OR: U.S. Department of Agriculture, Forest Service, Pacific Northwest Research Station. 72 p. (Everett, Richard L., assessment team leader: Eastside forest ecosystem health assessment; Hessburg, Paul F., science team leader and tech. ed., Volume III: assessment).

Huff, Mark H.; Ottmar, Roger D.; Alvarado, Ernesto [and others]. 1995. Historical and current forest landscapes in eastern Oregon and Washington. Part II: Linking vegetation characteristics to potential fire behavior and related smoke production. Gen. Tech. Rep. PNW-GTR-355. Portland, OR: U.S. Department of Agriculture, Forest Service, Pacific Northwest Research Station. 43 p. (Everett, Richard L., assessment team leader: Eastside forest ecosystem health assessment; Hessburg, Paul F., science team leader and tech. ed., Volume III: assessment).

Jurgensen, M.F.; Harvey, A.E.; Graham, R.T. [and others]. 1997. Impacts of timber harvesting on soil organic matter, nitrogen, productivity, and health of inland Northwest forests. Forest Science. 43(2): 234-251.

Larsen, M.J.; Jurgensen, M.F.; Harvey, A.E. 1981. Athelia epiphyla associated with colonization of subalpine fir foliage under psychrophilic conditions. Mycologia. 73: 1195-1202. 
McCool, Stephen F.; Burchfield, James A.; Steward, D. Allen. 1997. Social assessment. In: Quigley, Thomas M.; Arbelbide, Sylvia J., tech. eds. An assessment of ecosystem components in the interior Columbia basin and portions of the Klamath and Great Basins: Gen. Tech. Rep. PNW-GTR-405. Portland, OR: U.S. Department of Agriculture, Forest Service, Pacific Northwest Research Station: 1872-2009. Chapter 7. 4 vol.

Meyer, W.H. 1938. Yield of even-aged stands of ponderosa pine. Tech. Bull. 630 . Washington, DC: U.S. Department of Agriculture. $60 \mathrm{p}$.

Minore, D. 1979. Comparative autecological characteristics of northwestern tree species - a literature review. Gen. Tech. Rep. PNW-87. Portland, OR: U.S. Department of Agriculture, Forest Service, Pacific Northwest Forest and Range Experiment Station. $72 \mathrm{p}$.

Moeur, M. 1992. Baseline demographics of late successional western hemlock/western redcedar stands in northern Idaho research natural areas. Res. Pap. INT-456. Ogden, UT: U.S. Department of Agriculture, Forest Service, Intermountain Research Station. $16 \mathrm{p}$.

Moore, Jim. 1994. Evidence of links between nutrition and forest health. In: Intermountain forest tree nutrition cooperative: Proceedings of a meeting; 1994 April 12; Spokane, WA. Moscow, ID: University of Idaho: 53-62.

Mroz, G.D.; Jurgensen, M.F.; Harvey, A.E.; Larsen, M.J. 1978. Effects of fire on nitrogen in forest floor horizons. Soil Science Society of America Journal. 44: 395-400.

Mutch, R.W.; Arno, S.F.; Brown, J.K.; Carlson, C.E. [and others]. 1993. Forest health in the Blue Mountains: a management strategy for fire-adapted ecosystems. Gen. Tech. Rep. PNW-310. Portland, OR: U.S. Department of Agriculture, Forest Service, Pacific Northwest Forest and Range Experiment Station. 14 p.

Mutch, Robert W. 1994. Fighting fire with prescribed fire: a return to ecosystem health. Journal of Forestry. 92(11): 31-33.

Nyland, R.D. 1996. Silviculture: concepts and applications. New York: McGraw-Hill. $633 \mathrm{p}$.

Oliver, C.D.; Larson, B.C. 1990. Forest stand dynamics. New York: McGraw-Hill. $467 \mathrm{p}$.

Pearson, G.A. 1950. Management of ponderosa pine in the southwest as developed by research and experimental practices. Monograph 6. Washington, DC: U.S. Department of Agriculture, Forest Service. 218 p.

Reynolds, R.T.; Graham, R.T.; Reiser, M.H. [and others]. 1992. Management recommendations for the northern goshawk in the Southwestern U.S. Gen. Tech. Rep. RM-217. Fort Collins, CO: U.S. Department of Agriculture, Forest Service, Rocky Mountain Forest and Range Experiment Station. 90 p. 
Rothermel, Richard C. 1983. How to predict the spread and intensity of forest and range fires. Gen. Tech. Rep. INT-143. Ogden, UT: U.S. Department of Agriculture, Forest Service, Intermountain Forest and Range Experiment Station. 161 p.

Rothermel, Richard C. 1991. Predicting behavior and size of crown fires in the northern Rocky Mountains. Res. Pap. INT-438. Ogden, UT: U.S. Department of Agriculture, Forest Service, Intermountain Forest and Range Experiment Station. $46 \mathrm{p}$.

Schmidt, Wyman C.; Wakimoto, Ronald H. 1988. Cultural practices that can reduce fire hazards to homes in the interior West. In: Fischer, William C.; Arno, Stephen F., comps. Protecting people and homes from wildfire in the interior West: Proceedings of the symposium and workshop; 1987 October 6-8; Missoula, MT. Gen. Tech. Rep. INT-251. Ogden, UT: U.S. Department of Agriculture, Forest Service, Intermountain Forest and Range Experiment Station: 131-141.

Schott, Jim. 1994. An industry perspective on fire control. Journal of Forestry. 92(11): 33.

Smith, D.M. 1962. The practice of silviculture. New York: John Wiley. 578 p.

Smith, D.M.; Larson, B.C.; Kelty, M.J.; Ashton, P.M.S. 1997. The practice of silviculture: applied forest ecology. New York: John Wiley and Sons, Inc. 537 p.

Turner, M.G.; Romme, W.H.; Gardner, R.H. 1994. Landscape disturbance models and long-term dynamics of natural areas. Natural Areas. 14(1): 3-11.

Van Wagner, C.E. 1977. Conditions for the start and spread of crown fire. Canadian Journal of Forest Research. 7(1): 23-24.

Van Wagner, Ralph. 1968. Survival of coniferous plantations following fires in Los Angeles County. Journal of Forestry. 66: 622-625.

Wagle, R.F.; Eakle, T.W. 1979. A controlled burn reduces the impact of subsequent wildfire in a ponderosa pine vegetation type. Forest Science. 25(1): 123-129.

Weatherspoon, C. Phillip; Skinner, Carl N. 1995. An assessment of factors associated with damage to tree crowns from the 1987 wildfires in northern California. Forest Science. 41(3): 123-129.

Weaver, H. 1955. Fire as an enemy, friend, and tool in forest management. Journal of Forestry. 53: 499-504.

Weaver, H. 1957. Effects of burning in ponderosa pine. Journal of Forestry. 55: 133-137. 
This page has been left blank intentionally. Document continues on next page. 
This page has been left blank intentionally. Document continues on next page. 
This page has been left blank intentionally. Document continues on next page. 
Graham, Russell T.; Harvey, Alan E.; Jain, Theresa B.; Tonn, Jonalea R. 1999. The effects of thinning and similar stand treatments on fire behavior in Western forests. Gen. Tech. Rep. PNW-GTR-463. Portland, OR: U.S. Department of Agriculture, Forest Service, Pacific Northwest Research Station. $27 \mathrm{p}$.

In the West, thinning and partial cuttings are being considered for treating millions of forested acres that are overstocked and prone to wildfire. The objectives of these treatments include tree growth redistribution, tree species regulation, timber harvest, wildlife habitat improvement, and wildfire-hazard reduction. Depending on the forest type and its structure, thinning has both positive and negative impacts on crown fire potential. Crown bulk density, surface fuel, and crown base height are primary stand characteristics that determine crown fire potential. Thinning from below, free thinning, and reserve tree shelterwoods have the greatest opportunity for reducing the risk of crown fire behavior. Selection thinning and crown thinning that maintain multiple crown layers, along with individual tree selection systems, will not reduce the risk of crown fires except in the driest ponderosa pine (Pinus ponderosa Dougl. ex Laws.) forests. Moreover, unless the surface fuels created by using these treatments are themselves treated, intense surface wildfire may result, likely negating positive effects of reducing crown fire potential. No single thinning approach can be applied to reduce the risk of wildfires in the multiple forest types of the West. The best general approach for managing wildfire damage seems to be managing tree density and species composition with well-designed silvicultural systems at a landscape scale that includes a mix of thinning, surface fuel treatments, and prescribed fire with proactive treatment in areas with high risk to wildfire.

Keywords: Silviculture, forest management, prescribed fire, selection, forest fuels, crown fire.

The Forest Service of the U.S. Department of Agriculture is dedicated to the principle of multiple use management of the Nation's forest resources for sustained yields of wood, water, forage, wildlife, and recreation. Through forestry research, cooperation with the States and private forest owners, and management of the National Forests and National Grasslands, it strives - as directed by Congress - to provide increasingly greater service to a growing Nation.

The U.S. Department of Agriculture (USDA) prohibits discrimination in all its programs and activities on the basis of race, color, national origin, gender, religion, age, disability, political beliefs, sexual orientation, or marital or family status. (Not all prohibited bases apply to all programs.) Persons with disabilities who require alternative means for communication of program information (Braille, large print, audiotape, etc.) should contact USDA's TARGET Center at (202) 720-2600 (voice and TDD).

To file a complaint of discrimination, write USDA, Director, Office of Civil Rights, Room 326-W, Whitten Building, 14th and Independence Avenue, SW, Washington, DC 20250-9410 or call (202) 720-5964 (voice and TDD). USDA is an equal opportunity provider and employer.

Pacific Northwest Research Station 333 S.W. First Avenue P.O. Box 3890

Portland, Oregon 97208-3890 
This page has been left blank intentionally. 